\title{
CULTURE, INNOVATION AND PERIPHERY: A THEORETICAL SKETCH AND SOME EVIDENCE FROM DIFFERENT PORTUGUESE CONTEXTS ${ }^{1}$
}

\author{
EDUARDO BRITO HENRIQUES ${ }^{2}$ \\ JOACHIM THIEL ${ }^{3}$
}

\begin{abstract}
The present paper tries to look at the culture-innovation nexus in periphery. Starting with a theoretical discussion on this issue, in which the role of culture in current capitalism is analysed, we raise the question whether the increasing importance of culture in the present economic context has been creating new opportunities for peripheral regions to innovate, namely by the valorization of tradition.

The paper will highlight the results of four case studies from the handicraft pottery sector. These achievements will then be confronted with an example of cultural political promotion in an urban area - Lisbon'94, European Cultural Capital, in order to unravel the political logic of culture and innovation in the periphery. The final section provides a brief conclusion, placing emphasis on the ambivalences which characterise peripheral modernisation processes and their cultural dimension. We argue that the ability of periphery to sustain development strategies based on the valorization of tradition depends primarily upon a successful management of these ambivalences.
\end{abstract}

Key-words: cultural industries, cultural policies, embeddedness, handicraft, Lisbon'94, Portugal.

Resumo - CULTURA, INOVAÇÃO E PERIFERIA: UM ESBOÇO TEÓRICO E ALGUNS EXEMPLOS COLHIDOS EM DIFERENTES CONTEXTOS PORTUGUESES - O presente artigo analisa as articulações entre a cultura e a inovação na periferia. Começando com uma discussão

1 This article is based on a paper previously presented at the EUNIT International Conference on "Industry, Innovation and Territory", Lisbon, March 1997.

2 Assistente da Faculdade de Letras, Universidade de Lisboa. Investigador do Centro de Estudos Geográficos da Universidade de Lisboa. Centro de Estudos Geográficos, Faculdade de Letras, Cidade Universitária 1699 LISBOA CODEX; tel: (351-1) 79402 18; fax: (351-1) 79386 90; e-mail: ceg@mail.telepac.pt.

$3 \mathrm{PhD}$ Assistant, Technische Universität Hamburg??-Harburg. Arbeitsbereich Stadt- und Regionalökonomic 21071 Hamburg. Tel: (49-40) 7718-3628; Fax: (49-40) 7718-2794; e-mail: thiel ${ }^{\circledR}$ tu-harburg.de; from 2/96 to 4/97 as EUNIT-fellow at CEG, Lisbon. 
teórica a respeito destas matérias, que inclui uma reflexão sobre o papel da cultura no capitalismo contemporâneo, coloca-se a questão de saber se a crescente importância da cultura no presente contexto económico tem criado novas oportunidades de inovação para as regiões periférias, nomeadamente por via da valorização da tradição.

$\mathrm{O}$ artigo apresenta quatro estudos de casos do sector da cerâmica artesanal portuguesa, complementados posteriormente com a análise de um exemplo de promoção cultural em espaço urbano - Lisboa'94, Capital Europeia da Cultura. A partir do confronto destas experiências procura-se descortinar as lógicas subjacentes à política de cultura e inovação na periferia, chamando a atenção para as ambivalências que caracterizam os processos de modernização periféricos e a sua dimensão cultural. Como conclusão, sugere-se que a capacidade das regiões periféricas sustentarem estratégias de desenvolvimento baseadas na valorização da tradição, como se defendeu inicialmente, depende no essencial da gestão bem sucedida dessas ambivalências.

Palavras-chave: indústrias culturais, políticas culturais, “embeddedness”, artesanato, Lisboa'94, Portugal.

Kurzfassung - KULTUR, INNOVATION UND PERIPHERIE: EIN THEORETISCHER ENTWURF MIT EINIGEN BEISPIELEN AUS UNTERSCHIEDLICHEN ZUSAMMENHÄNGEN PORTUGALS - Der vorliegende Artikel untersucht die Zusammenhänge zwischen Kultur und Innovation in peripheren Regionen. In einer theoretischen Diskussion wird zum einen die Rolle der Kultur im heutigen Kapitalismus analysiert und zum andern der Frage nachgegangen, ob und inwieweit die gegenwärtig zu beobachtende Zunahme der ökonomischen Bedeutung von Kultur durch die Aufwertung von Tradition neue Chancen der Innovation für periphere Regionen mit sich bringt.

Im Anschluß daran werden die Ergebnisse von vier Fallstudien aus dem portugiesischen Keramikhandwerk dargestellt und diese mit dem Fall Europäische Kulturhauptstadt Lissabon 1994 als Beispiel von Stadt-Kulturpolitik konfrontiert. Damit soll insbesondere die politische Logik von Kultur und Innovation in der Peripherie thematisert werden. In den abschließenden Schlußfolgerungen wird betont, daß periphere Modernisierungsprozesse und ihre kulturelle Dimension immer von Ambivalenzen gekennzeichnet sind. Es wird argumentiert, daß die Innovationsfähigkeit peripherer Regionen in starkem Maße davon abhängt, wie mit diesen Ambivalenzen umgegangen wird.

Schlagwörter: Kulturindustrie, Kulturpolitik, “embeddedness”, Kunsthandwerk, Lissabon'94, Portugal.

\section{I - INTRODUCTION}

Culture has been experiencing a tremendous actuality in academic discussion during the last years, including in geography. The cultural dimension of economic development has particularly become a fashionable issue, due not only to the current tendency to cultural production being more and more integrated in market logics, but also because it has been noticed that cultural factors play a more important role in economic growth than traditionally was assumed.

In this paper we consider the relations between culture, innovation and 
economic development in periphery contexts, raising the question whether the growing importance of culture in current capitalism may create new opportunities for peripheral regions and, namely, in what extent it encourages peripheral territories to take advantage of persisting traditional structures. Thus, the paper starts with a theoretical discussion on these issues. Then, in the following sections, we try to show how these processes work in reality and what are the conditions which aid and hinder its success using four Portuguese case studies from pottery handicraft sector. Finally, an example of cultural promotion in an urban area will be analysed - Lisbon'94, of which study we will yet try to learn some lessons on the logics and problems of cultural policies in periphery contexts.

\section{II - CULTURE, INNOVATION AND PERIPHERY: A THEORETICAL SKETCH}

Dealing with the cultural dimensions of economy is becoming, as already pointed out in the introduction, a common activity within academy, namely in geography, involving a growing number of authors as influent as D. Harvey or A. Sayer. These names represent, besides, two different approaches to culture-economy nexus which somehow constitute the paradigms of the ongoing discussion. The first, which we could call "culture as a commodity"-approach, represented by Harvey in its famous "inquiry into the origins of cultural change" (HARVEY, 1989), displays the increasing integration of culture in a capitalist economic logic, while the later, here "culture as the bed of economy"-approach, emphasises the cultural base of economic growth (see SAYER, 1994). In the following lines we briefly present these two broad strands of discussion linking them with the concept of periphery.

\section{Culture as a commodity: from criticism to pragmatism}

The first and probably most famous argument concerning the integration of culture in the process of capital accumulation might be the introduction of culture industries concept by Horkheimer and Adorno in the 1940s, within their Dialectic of Enlightenment. Heavily influenced by the occurrences of fascist Germany, they traced a future capitalism in which people are mere passive victims of a manipulative global culture, thus without any chance for own decision and condemned to consumption (ADORNO, 1991; JACKSON and TAYLOR, 1996).

A lot of scientific work followed this structuralist approach, mainly oriented towards the persuasive effects of culture and less stressing the aspect of real cultural production. This last topic only appears in the course of discussions on postmodernity, which was first dominated by arts and architecture and then theorised also in philosophy and criticised by political economy.

There are chiefly two protagonists from political economy involved in this controversial discussion: the above quoted D. HARVEY (1989) and F. JAMESON 
(1984), the later with his essay on the "cultural logic of late capitalism".

Harvey's position tends to be structuralist and sceptical as Horkheimer's and Adorno's argument, setting in, however, at a different point. What he indicates as the "origin of cultural change" is a new quality of capital circulation. According to HARVEY (1989), capital becomes itself a productive force thereby integrating previously "independent" areas such as culture: "precisely because capitalism is expansionary and imperialistic, cultural life in more and more areas gets brought within the grasp of the cash nexus and the logic of capital circulation" (op.cit.: 344).

Jameson's article, in terms of diagnosis, comes to similar results, only supposing a different cause for those changes in the process of cultural production since it puts the emphasis on technological questions. Yet JAMESON (1984) differs, at least at first glance, in his assessment of this shift towards the integration of culture in the processes of capitalist reproduction. His main argument insists on a radically dialectic rather than moral approach, considering the cultural evolution in late capitalism both as catastrophe and progress. The negative aspects basically corresponds to the loss of the critical distance that had previously constituted one of the main social qualities of culture.

These fundamentalist issues are being continued as the recent discussion on the concept of culture in geography shows. The social materialisations of this shift, however, are being taken up by much more pragmatic scholars, in order to take advantage of the increasing economic importance of culture for regional development, thereby showing a distinct interpretation of the positive (or innovative) aspects that JAMESON (1984) tries to point out in a more universal sense. In this way, the term "culture industries" is being reborn and gains new facets. As A. SCOTT (1996: 319) puts it: "An assumption frequently made by local economic-development practitioners is that high-technology industry represents the one best pathway to regional prosperity. As the present investigation has shown, however, cultural-products industries can also be an extremely powerful vehicle of job creation and growth". In the same sense, other less paradigmatic or less successful cases than Los Angeles (as in Scott's work) were explored. There, culture appears as a motor of economic regeneration in deindustrialised localities, albeit not as a universal remedy (HUDSON, 1995), or as a hitherto generally neglected means for the generation and protection of regional employment (KUNZMANN, 1995), not only by having "a special significance within the sectoral structure of regional economies (direct output effects) ..." but also by displaying "... a particular productivity in the context of the economic, social and ecological development of regions, ...(indirect output effects)" (AG KULTURWIRTSCHAFT, 1995: 6). Assuming this approach, we cannot only find a much clearer relation between culture and innovation than in the basic discussions, being able to exploit the economic importance of a cultural-products-sector, but also can meet a hint towards a second shaping of this relation, which have to do with the concept of indirect output effects of cultural industries: the role of culture as precondition for an innovative economic performance. This aspect leads us to the next section. 
2. Culture as "the bed of economy": from collective consciousness to the ability to change

The argument summarised and criticised by SAYER (1994), quoted in the introductory part of this chapter, starts from an analytical realisation: as economic actors are human beings, their performance depends heavily on social relations. In this sense, an "atomistic" view of economy is refuted, and substituted by a concept of embeddedness, thus considering "economic action and outcomes" as being "affected by actors' dyadic relations and by the structure of overall network of relations" (see GRABHER, 1993: 4). So far, one cannot recognise a relation between culture and innovation. However, it is again an assumed shift within the organisation of capitalist production, respectively the observation of new phenomena in this context, which encourages a new emphasis.

In theoretical terms, the concept of innovative milieu, developed by the GREMI group, appears to be the most "culturally informed" approach. M. STORPER (1995), in a reprise of the whole discussion on "regional economies", argues that the milieu "rejoins a key theme of the Marshallian school: that there is something intangible, 'in the air' ..., which permits innovativeness to proceed in some places and not in others" (p.203), criticising the lacking explanation of what basically permits this innovativeness.

Without proposing a review of the whole body of literature dealing with these issues, we just attempt to point out two dimensions that emphasise the cultural aspects within at least most of the discussions.

First, there is the suggestion to consider a milieu as reducing complexity, acting as a filter between the inside and the outside of a network, this is, of itself (LÄPPLE'S, 1994: 43). In fact, nearly all approaches to innovation and embeddedness introduce the existence of a certain "identity" or "collective consciousness" as a precondition for innovativeness. There are, for instance, arguments chiefly dealing with the concept of institution such as by A. AMIN and N. THRIFT (1994), who insist on "institutional thickness" as remedy for competitiveness. This thickness, besides being characterised by "hard factors" such as "a strong institutional presence" or a "commonly held industrial agenda", is highly dependent on "soft factors", this is "shared rules, conventions or knowledge" or "various forms of socio-cultural identification (AMIN and THRIFT, 1994: 14f.). Storper's argument, being raised as a kind of completion of the discussion, emphasises a certain richness of transactions, not only as "traded interdependencies" (input-output relations), but also, and more importantly, as "untraded interdependencies", which include, besides labour markets and the presence of public and semi-public institutions, cultural conventions, norms and values, these constituting "worlds of production" enabling economic actors to cope with all kinds of uncertainty (or complexity) within the economic process (STORPER, 1995: 208). One could cynically add "...or not", thereby invoking the second cultural dimension of the embeddedness-debate. 
D. LÄPPLE'S (1994) argument of the filter function, for instance, is drawing on empirical work on the Ruhr, mainly to show the negative effects of a filter on innovativeness. The "old boys coalitions" of steel production and coal mining constitute a milieu with an extremely strong filter function, but they do rather hinder than aid the innovativeness of the Ruhr economy, therefore labelled by Läpple as a "sclerotic milieu". In this sense, the author points out another function, namely that of producing positive feedbacks, which can have both positive and negative effects, these depending on the peculiar constitution of the milieu (op.cit.: 42). A further dimension is added by D. NORTH (1991) when he tries to illuminate the interplay between institutions and the performance of economies in the history of capitalism. Starting from a broad concept of institutions as both formal and informal (this is, cultural) constraints "that structure political, economic and social interaction", he considers the capability of institutions to evolve, respectively to change, as the crucial point of economic performance (op.cit.:97). Raising the argument that this ability is not equally distributed in the world we advance to the next section.

\section{Systematically avoided, so far: the role of space}

It is simply impossible to deal with the embeddedness debate without stressing the spatial dimension. In fact, "territory matters" seemed to be one of the lessons to be learned from success stories of "industrial districts", "new industrial spaces", or "regional economies". Looking at the other culture discussion ("culture as a commodity"-approach), we also discover an emphasis on the spatial dimension, for instance, in the distinction given to the city, by JAMESON (1984) as well as HARVEY (1989), as a place where the cultural change is particularly manifested or, in a more practical sense, in SCOTT'S (1996) insistence on the importance of image-producing-complexes for innovative economic performance (which does certainly suggest a distinct spatial dimension from the mere embeddedness in regional networks, even if there are linkages as indicated by the term "indirect output effects"). What can these different interpretations of the new importance of a spatial dimension mean and how could they be conceptualised?

A first and fruitful approach is provided by the strong criticisms which have meanwhile surged against the over-emphasis on "territorialisation" of the ongoing change in capitalism. It was criticised that simply the internal situation of successful territories should be the base for a new period in capitalist development. The protagonists of these arguments, AMIN and THRIFT (1992), proposed a focus on the global-local nexus as an appropriate analytical point of departure. In their further work on this issue, they follow a more strategic perspective, looking for a remedy for "holding down the global" and, subsequently, finding the catchword of "institutional thickness" as a precondition for successful territorial performance within a globalising world. In this way, they turn around - to a certain extent - the logic of the regional economies: instead of an "active" contribution to a new 
period of capitalist development, territories are forced to "react" to a globalising capitalism, in order to avoid or minimise negative outcomes.

A more radically analytical approach is pursued by LÄPPLE (1991) in his concept of a matrix-space, which is, besides depicting four spatial dimensions (displaying the duality of agency and spatial structure - "substratum" - and adding two mediating factors: regulation, and a system of representations), based upon a three-level model (local or micro, regional or meso, national/global or macro). In this sense, it does not matter if the regional level acts or reacts in relation to its development in the global world-space. What matters is that the relation between the levels constitutes the driving force for "the complex process of destructuring and restructuring of social spaces", with the polarity of the "concrete place" and the "global space" representing the "central contradictory constellation" in this context, which is mediated by the regional meso-level (op.cit.: 198f.). This mediation process - or better: this articulation between territories and the world-economy - appears to be a solution for our spatial dilemma, since it enables us to include both the embeddedness debate and the world-space of multinational capital. However, and again, we have to insist that this articulation takes on different shapes which may be responsible for spatial unevenness. Thus, we finally reach the third concept of our theoretical framework: the periphery.

\section{The role of the periphery}

In a very similar way as Läpple deals with the structure of space, F. Braudel, in his work on the emergence of capitalism, attempts to describe economic reality as a model of different strata, distinguishing capitalism (as a world-wide acting, domination oriented system), market economy (as a competition oriented system) and the material civilisation (as an exchange and subsistence-oriented system) (BRAUDEL, 1985). In his work, he draws essentially on Wallerstein's theory of a modern world-system surged upon the spatial hierarchisation (or hierarchic division of labour) in the course of the colonisation process (WALLERSTEIN, 1974), considering this system of core, semiperiphery and periphery, however, only as the surface of the economic reality of the world, shaping and influencing, as well as being considerably influenced and shaped by the strata below.

It is true that Braudel's model is only in a limited sense a spatial model due to its focus on forms of economic relations. However, in combination with a spatial context (as Läpple's matrix-space) it provides an encompassing framework for the explanations of spatial unevenness or, in other words, the surgence (or existence) of cores and peripheries. In this sense, unevenness is a condition (and result) of capitalist societies, being determined by the role of each territory within the world-system. P. KNOX and J. AGNEW (1989) take up this complex set of arguments within their The Geography of the World-Economy, describing every territory as a related but unique part of the whole world-economy (p. 5). Regarding the periphery, they indicate four distinct types, each depending on its degree of 
incorporation into the world-system: external area, contact periphery, marginal periphery and dependent periphery. In our argumentation, we keep the broader concept of an "articulation with the world-system" (THIEL, 1995: 30) so as not to remain limited to a continuum of incorporation, assuming that different, even contradictory characteristics of the periphery, such as externality and dependence, can be identified in the same territory.

Nevertheless, it is necessary to point out possible characteristics of the periphery in order to surpass the neutrality of the term "articulation", supposing for the periphery a subordinated role in the world-economy. For this purpose, we go back to the "classic" conceptualizations of core-periphery relations, using spatial remoteness (from the centres) and underdevelopment (both in a sense of backwardness and dependence) as helpful starting points.

Being far away from our first focus, the different relations between culture and innovation, it could be helpful to summarise a preliminary correlation of our three key concepts, hereby turning the previous order around, thus beginning with periphery.

Periphery is a relational concept, that is, it may only be understood alongside with its counterconcept: the centre or core. However, a concept of periphery must not remain limited to this duality, as the "classic" theoretical approaches usually do, but has to be based upon a relational concept of space, thus trying to unravel the attribution of roles to territories in a wider context. In a simplified form, we can depict this attribution as concurrence of the internal (local/regional) and external (national/global) logic of a given territory. Between these two logics, (not only) peripheral regional development occurs.

But neither the concurrence of internal and external factors nor each of them in itself act as a purely economic dimension of value-added transfer, etc. On the contrary, cultural factors function in a decisive way both as mediators of this concurrence and as expression of the respective logics. D. IPSEN (1990), for instance, offers a concept of periphery in which the cultural mediation between the external and the internal logic constitutes the crucial factor. For him, "periphery is not a characteristic of a region, but it describes the relation people have to this region. This relation, for its part, is derived from a determined value system or conception of development, which is implicitly or explicitly considered to be worth striving for. Only based upon a hegemonial conception of development it is possible to order territories hierarchically, according to how far each one is able to accomplish the conception" (op.cit.: 71).

In relation to the three levels of the matrix-space, Ipsen depicts the interplay of the dominating global macro-space and the micro-space of daily life, being the results of this interplay manifested in the meso-space, the region. However, the mediation between these levels neither occurs continuously, nor does it show a static relation, something Ipsen points out by using the example of La Palma island, certainly not considered peripheral by the elder generations of inhabitants, but rather as "the focal point of their existence", whereas the younger generations 
are more oriented towards the bigger Canary Islands (IPSEN, 1990: 70). Thus, it is mainly in cultural terms that territories show peculiarities in the face of a global world-system, respectively that the "extinct mini-systems" (WALLERSTEIN, 1974: 7) have nevertheless maintained a certain degree of autonomy.

This brings us back to the starting point, namely to the two different conceptualizations of the culture-economy nexus, both emphasising a spatial logic, either as a world-space of the multinational capital or as the internal characteristics of a given region. Would it not be appropriate to interlink these approaches, conceptualizing them - at least in analytical terms - as cultural expression of the internal and the external logic of regional development, the process of mediation between these logics being the crucial point to be studied? Viewed in this sense, both the shift towards the integration of culture in economic processes and the increasing importance of the cultural preconditions of a territory for its economic performance, would gain new facets. We will try - in a last step - to apply this framework to peripheral regions, aiming at finding new opportunities for them to innovate.

5. Culture, innovation and periphery: valorization of tradition?

Both approaches, the "culture as a commodity" case as well as the "culture as bed of economy" case, presuppose a shift within capitalism, tending even to use the same theoretical base, namely regulation theory. Within the whole body of literature dealing with the shift from Fordism to Post-Fordism, respectively with its results on spatial restructuring processes, there are two issues which could be applied to the periphery. Both can be seen, in a first step, from a phenomenological stand-point, stating that the clear Fordist spatial patterns tend to be dissolved or at leased superposed by new developments, labelled with the catchwords "fragmentation of space" or "spatial patchwork". Previously insignificant territories have been experiencing periods of considerable economic growth, disturbing the traditional order of developed and underdeveloped regions. The two explanative approaches try to unravel this process of reorganisation from evolutions outside the periphery, in the first case, and from evolutions within the periphery, in the second case, thus dealing with what we have called the "concurrence of the internal and external logic of regional development". Both, however, use the persistence of traditional structures as starting point for explanation and both do have an important cultural dimension. We will call them, according to the focus on tradition, the "renaissance of singular places" and the "resort to own traditional qualities".

5.1. The renaissance of "singular places" 4

4 See Ipsen (1988: 30). 
According (again) to Ipsen, the peripheral restructuring process triggered by the shift from Fordism to Postfordism is based upon a change within the aesthetic paradigms of the style-determining social class, labelled by him as the surgence of a class of well-paid and well-trained urban professionals who tend to search for spatial singularity. The author explains this tendency with the rationalisation of the working-life of these white-collar workers, respectively a total abstraction of space and time. Caused by this tendency to a disenchantment of their professional life, this group "tends to seek for 'enchantment' of the dimensions time and space within their daily life whenever a 'rational penetration' is not required". "Certain regions are specially suited for these needs" (IPSEN, 1986: 148f.). They embody "singular places" in a double sense, namely due to their singular landscape, as well as due to the concrete relation of the regional population to this landscape.

In this context, one can detect an interesting correspondence between Ipsen and Harvey's argument of the demand side of the cultural mass of postmodernism: "... the new social layers that came into existence with the formation of the cultural mass and the rise of new white-collar occupations in finance, real estate, law, education, science, and business services provided a powerful source of demand for new cultural forms based on fashion, nostalgia, pastiche, and kitsch - in short, all that we associate with postmodernism" (HARVEY, 1989: 348). However, whereas Harvey's approach is much more sceptical, directly derived from the logic of capital accumulation, Ipsen considers the aesthetic reorientation rather as a self-reflexive side-effect of social change, surged from a need within a certain class.

Nevertheless, Harvey stresses an important criticism or limitation of this increasing aestheticism, which is seen by Ipsen as well: Postfordism implies only partly a shift towards professionalisation in the sense of requalification of workforce; on the other hand, there is a lot of evidence of the contrary, namely the dequalification within untrained service-jobs and increasing impoverishment (IPSEN, 1988: 29; HARVEY, 1989: 329f.). Furthermore, the creation of new opportunities for previously peripheral regions has to be seriously questioned, since the new aestheticism does not suggest a really new role for them; rather a more sophisticated form of dependence, due to the production of a rural idyll by the centre: "Thus, the modernisation of the autochthonous population is slowed down - consciously or unconsciously, since the discoincidence is functional" (IPSEN, 1986: 149).

\subsection{The resort to own traditional qualities}

This supposed asset of peripheral regions is closely linked to the above cited 'bed of economy'-debate, thus starting from the same cultural emphasises raised in this context, this is, the factors "identity" and "ability to change". In the case of the latter, pre-modern characteristics such as a household-centred economy and informal networking structures are more likely to be found in peripheral regions. At the same time, such "peripheral performance-patterns" are supposed to enable 
economic agents to cope with a flexible economic environment, being a mixture of individual responsibility and informal (regional) solidarity considered the reason for the "reemergence of regional economies" (SABEL, 1989: 22). This regional solidarity, for its part, lies at the heart of the people's relation to their region, encouraging in this way a collective effort, a sort of positive regionalism, not as opposition to modernisation - as in the seventies - but as its inherent part (LINDNER, 1994).

It is obvious that this vision of a new opportunity for an endogenous peripheral development trajectory, substantially influenced by the regional success stories of the Third Italy, has to be questioned as well, namely on an empirical and on a theoretical level. Firstly, the regional success of the industrial districts has by no means been a pure traditional re-emergence but rather a successful linkage of traditional structures into a wider context. Secondly, and as pointed out above, the argumentation suffers mainly from its internal territorial approach, being both the capability to be flexible and a positive regional identity considerably dependent on external factors. Particularly the latter, as shown by Ipsen's concept of periphery and his further work on similar issues (IPSEN, 1993), is nothing more than the cultural expression of the articulation of a territory with the world-system.

\section{Outlook}

Given these rather sceptical conclusions, it seems necessary to withdraw at least partly our argumentation. Although the shown tendencies towards the valorization of tradition in the periphery can by no means be considered a linear way to economic success, both a new aestheticization of periphery and a considerable growth of formerly rural or semi-rural regions are visible phenomenons. Thus, it is - or has to be - the task of empirical work to unravel the inherent logic of innovation within the periphery, respectively of its cultural base. The framework may be established by the preceding outline. Hence, how is the valorization of tradition put forward in reality and what are the conditions which hinder and aid its success? A first answer is given by the previous lines: it is certainly not tradition alone which matters. The rest is left for the remainder of this paper.

\section{III - CULTURE, INNOVATION AND PERIPHERY: SOME EVIDENCES FROM DIFFERENT PORTUGUESE CONTEXTS}

\section{Valorization of handicraft activities: four cases from northern portugal}

There is some evidence that the valorization of tradition has gained a new status within the Portuguese local development policy. On the one hand, forced by an enduring process of population deserting from nearly all rural areas of the 
country ${ }^{5}$ and, on the other hand, encouraged by the hope that the new urban white-collar middle class would cause a demand-boom for traditionally manufactured products, even the Regional Development Plan (PDR), which constitutes the base of the distribution of European funds for the period from 1994-1999, considers the market valorization of traditional products, organisation of forms of pluriactivity and diversification of sources for the family income as one of the strategic lines to be followed in order to reduce both inter-and intra-regional asymmetries (see MARQUES and PORTELA, 1994). Consequently, there is a whole body of public, semi-public and private institutions being engaged in the promotion of handicraft products, from traditional food, textiles and clothing (this having the greatest importance in employment terms - MOREIRA, 1994) to basketry, pottery, etc., putting forward training courses, creating publicity with catalogues, realising temporary or permanent handicraft fairs, establishing commercialisation networks, in other words, trying everything to support an economically successful performance of traditional activities.

However, these interventions are facing a series of problems linked to a severe restructuring process the traditional activities have undergone within the last decades in the course of which their original purpose has been seriously questioned. Handicraft activities have been indissoluble part of a local rural society, accomplishing practical and economic tasks within this society and in principle never leaving it. By social evolutions such as the emigration wave of the $60 \mathrm{~s}$ and the subsequent process of desertification, as well as the surgence of competitive industrial products, both the society in itself and its materialised outputs had to look for new modes to survive.

The following cases display four examples from the pottery sector showing possible attempts to modernise the traditional handicraft activity, thereby capturing new markets using traditionally as a special feature. The main characteristic of these examples may be their diversity, not in terms of product but in what concerns the process and the outcome of the "innovation by tradition".

\subsection{Inventing history: the Cock of Barcelos}

There is certainly no souvenirshop all over Portugal where one cannot buy all sizes of pottered cocks, strikingly coloured with a gleaming red comb, stemming from Barcelos. Equally, nearly every Portugal tourist guide offers the corresponding traditional local legend which this pretty puppet is based upon, telling different versions of the story about a pilgrim to Santiago de Compostela who (or whose son) was condemned to death but who succeeded in waking up and making crow a fried cock the judge was just going to have for dinner, thereby

5 See, e.g., C. Cavaco and A. Ramos (1994: 21f.). 
finally convincing the latter of his (or his son's) innocence.

What only few people know is that actually the two stories do not have any interlinkage. Up to the 1960s, either the pottered puppet or the religious legend was mentioned always separately, and the shift towards a somehow paradigmatic symbol of tourist Portugal seems to be the result of hardly reconstructable historical coincidences of political voluntarism, tourism marketing, along with local technical innovations within the ceramic sector.

The puppet in fact constituted one of the most important products of artistic handicraft pottery in the former concelho of Prado (Barcelos), in the Northwest of Portugal. A report on the pottery of Prado, written at the end of the last century, refers to an abundance of cocks produced by the rural artists, by far exceeding the other puppets in terms of quantity, size and lavishness of the decoration (РEIXOTO, 1899). The author attributes the importance of the figure to the role of the cock in the rural environment, the expression of masculinity, on the one hand, and the setting of the beginning of the day, on the other hand (op.cit: 39). In the traditional regional context, pottered puppets were generally used as a toy for the children of the lower rural and urban classes, having the latter maintained rural habits in an urban context in northern Portugal, or as an incentive for the popular fairs. The ways of commercialisation did never surpass fairs (reaching, however, the whole northern part of Portugal, at least in the last century) and the products in general only were bought by the typical visitor of these fairs, i.e., the lower rural classes.

The Estado Novo tried to exploit the cock as a figure compatible to their ideology of a rural, but powerful Portugal, firstly visible within the Exposition of the Portuguese World in 1940, in the course of which the cock ranked among the allowed pieces to be sold to the visitors. However, fascist propaganda literature on Portuguese popular arts in 1940s did not give any tourist importance to it, merely stressing the local significance of the animal (see LAGE et al, 1940). The first attempts to use the animal as a symbol for the country may have been undertaken, according to C. A. Ferreira de Almeida, at the end of World War II, on the one hand due to the rural ideology, on the other hand caused by a preceding process of technical innovation within the local system of Barcelos, in the course of which the potters succeeded in using the wheel for the puppet production instead of the hitherto prevailing hand modelling, thereby manufacturing a more or less standardised cock with uniform appearance (ALMEIDA, 1990). The same author considers this innovation mainly as fostered by the local fair of Barcelos, where the abundance of the pottered animal still nowadays constitutes one of the main features (op.cit: 85, 99).

The legend, for its part, has always been linked to the pilgrimage to Santiago, thus appearing at a variety of places throughout Europe. By no means it constituted a single "locally owned" story of Barcelos, and was rather transmitted by pilgrims on their ways through Europe, finding different shapings of relations to local contexts. In Barcelos a statue recalls the story, depicting only one part of the miracle, this is, the ascension of the dead, though innocent, son of the pilgrim by 
St. Tiago, furthermore a cock above this scene and a cross on the top.

Only in the sixties, a director of an ethnologic museum in Oporto and politician of the Salazar's state linked these two stories, publishing a book being followed by a local conference in which the author presented his "research" to local politicians and scientists, thereby creating a new legend (ALMEIDA, 1990: 100). This creation coincided with the period of Portugal's entry into the mass tourism markets (see HENRIQUES, 1996). From 1960 to 1970 the number of hotel overnight stays increased by $227.5 \%$. The Algarve began to attract the attention of European tourists as a virgin region, considerably fostered by the opening of the Faro airport and the commemoration of Henry the Navigator in Sagres, the cock appearing abundantly in this context as well. Although it is not clear how the perpetuation of the myth occurred exactly, it seems to be this coincidence which lies at the heart of the tremendous success of a local tradition.

\subsection{Discovering remains of a lost art: Rosa Ramalha ${ }^{6}$}

In spite of being the most important object among the hand-modelled clay puppets, the cock by no means constituted the only example of puppet pottery in Barcelos. Popular art was generally based on the daily experiences of rural life, depicting animals, agricultural activities, along with images and superstitious interpretations of religious figures and important social personalities such as the king (PEIXOTO, 1899). It was so to speak a profoundly rural art by which the potter tried to "imitate the nature that surrounds him" (op.cit: 37). The artists were in general illiterates, not even possessing a specially high status within the villages where they lived, rather on the contrary ${ }^{7}$. At the same time as the cock of Barcelos was experiencing its big boom as tourist symbol, i.e., in the beginning 1960s, the overall puppet pottery became famous all over Portugal, although its original significance had actually ceased to exist. At that time, hand-modelled clay puppets did not belong to the normal decorative pieces of the rural households in Barcelos. Furthermore, the success of hand-modelled puppets was independent from the success of the cock, but linked to the personality of an old woman who was still continuing this tradition in an astonishingly original way.

Rosa Ramalha ${ }^{8}$ was born in the 1890s and learned the art of pottering figures with seven years, working in the house of her parent's neighbours. With thirteen she married a miller, leaving the ceramic activity in order to dedicate her further life to her family and to the support of her husband's profession. When her husband died, she had not produced any puppet for 50 years, yet immediately

\footnotetext{
6 In the public discourse, mostly the name Rosa Ramalho is used, corresponding to official conventions, but not to the local habits, which preferred the female ending for women's surnames in the case of women who "ruled" their household.

7 Personal interview with Eugénio Lapa Carneiro, in 1997.

8 The biographical information about Rosa Ramalha draws on Flowers (1967), along with two personnal interviews in 1997 with Eugénio Lapa Carneiro and António Teixeira de Sousa.
} 
restarted after his death, already nearly seventy years old, being able to continue her art as if she had not interrupted it at all. She sold her products on the local fair of Barcelos where she was discovered by a well-known Portuguese artist and professor at the Oporto School of Fine Arts (António Quadros), who took her to the school presenting Rosa Ramalha and her work to his art students.

Subsequently, she got the opportunities to sell her products first at national handicraft fairs, then even Lisbon galleries began to expose Rosa Ramalha's pieces. The TV became aware of her, groups of artists tried to involve her in discussions on modern arts, showing her a variety of works and expecting her expert comment. Her originality, that is, the "taking-up" of techniques of the last century on the one hand, in combination with the invention of new elements, which resulted from both an extraordinary talent and a very clear idea about the world around her, on the other hand, were considered her special assets explaining the success of a person which represented an activity with actually rather little value placed upon.

The "story" of Rosa Ramalha, who was not able to write more than her initials RR in order to carve it into her pieces, did not remain without consequences for the Barcelian puppet production. Still in 1991, her pieces were used for an exposition in the course of Europalia, in Brussels, organised by the Portuguese Institute for Employment and Professional Training (IEFP). Besides her work, other similarly working and still living artists not only from Barcelos were exposed, among them Rosa's granddaughter Julia who was supposed to continue Rosa's work. However, a new generation of potter artists has not been born, and already Julia's work does not show the originality of her grandmother, as the interviewed experts stressed. Thus, besides museal nostalgia, puppet pottery as an art apparently had with Rosa Ramalha the beginning of its end, due to its indissoluble linkage to a society that no longer exists.

\subsection{Importing the export: the Reimmigrant-Potter}

Barcelos, or better: the former Prado municipality, is a famous Portuguese example not only for puppet-pottery (figurado) but for utilitarian pottery as well, this overall production being due to an abundant existence of different qualities of clay in this area. The commercialisation at the end of the last century was extended over the whole north of Portugal, even reaching Galicia (РегхоTO, 1899). The traditional products have been mainly red clay pots and kitchenware (glazed or not), the latter sometimes decorated with patterns carved into the clay. These products are still existing today, sold in more decorative styles in special handicraft shops at the tourist places, that is, as tableware, sometimes painted with white spots, or at local and 
regional fairs, for more utilitarian purposes, namely as pots and vases or other coarse kitchenware. The traditional decoration has disappeared.

There is one case deserving attention stemming from this tradition, but offering a completely different product, being able to place it in the European market. A potter from Barcelos ${ }^{9}$, whose father and grandfather already had the same activity, emigrated with his family to France in the 60s, thus following the example of thousands of rural Portuguese at that time. The difference probably was that the couple was able to maintain its previously executed activity, finding jobs in a Provençal handicraft enterprise, staying there for sixteen years, towards the end even as bosses paying a rent to the former owner. Getting into trouble with their former boss, they decided to return to Portugal, taking the activity including the design of the dishes with them, only adding a "Portuguese colour" - blue, and began to produce as a one-man enterprise for local clients and for friends in France, who distributed the tableware there. What they, hence, did not adopt from the local tradition was the red colour of the baked clay, opting for a finer quality, which is yet available in the region as well, being originally used for finer tableware copying the big national china producers (PEIXOTO, 1899).

After some years the dishes were exposed in a local handicraft centre of Barcelos, for obvious reasons specialised in pottery. From there on, the demand increased rapidly, however less so in Portugal but more on the part of foreign clients or Portuguese commerciants who specialised in distribution for tourists. Nowadays, a view into the little warehouse of the enterprise shows an impressing quantity of tableware: the family enterprise works with eight persons, including couple's son and daughter, exporting more than $80 \%$ of the production directly to stores or distributors abroad, specially France, United Kingdom and Spain. The rest is bought by national commerciants who sell it at the tourist places all over the country, avoiding, however, the classic souvenir-shops. The sales locations are either special stands at special places such as the Lisbon St. Jorge castle or the Ladra Fair, or handicraft shops of a more sophisticated nature, although the final prices of the dishes are low. In the course of the economic success, and in order to cope with the rapidly increasing demand, the production itself was modified, making the tableware more standardised both in form and colour, thereby loosing a part of its original characteristics.

\subsection{Unable to be modernised: Black Pottery}

Traditional Portuguese pottery (mainly the utilitarian part) can be divided in two groups: on the one hand, the red earthenware, on the other hand, the same design, only having a black colour. The difference is caused by distinct baking processes. A low in oxygen exposure durting baking in a covered earth-hole, using

\footnotetext{
9 The information on this case was obtained by a personal interview with the potter in 1997, along with some personal experiences during the last years.
} 
broom and similar bushes as fuel, being responsible for the black colour.

Originally there have been 53 localities in Portugal where black pottery was practised, including the former Prado concelho (FERNANDES, unpublished list), but only three of them maintain the activity, thereby, as whole potter villages, being the only cases in Europe (TOBIAS, 1986). Two of these villages have been studied in the 1970s and the 1980s (FERREIRA, 1983, TOBIAS, 1986), both being localised in the district of Vila Real.

The black pottery villages display quite well the recent evolution of Portuguese handicraft activities. Still in the 1950s, they constituted real local "clusters", nearly every household practising the production of black kitchenware, either being used as a second currency not only in the village itself but in the closer surrounding as well, or sold generally by the potters' wives, touring by foot through an area with a diameter of about $100 \mathrm{~km}$ (FERREIRA, 1983).

The process of restructuring beginning from the 1960s onwards, mainly caused by the emigration movement, shows its results above all in a substantially reduced number of craftsworkers: Bisalhães, one of the villages, near Vila Real, decreased from almost 50 in the 1950s to 16 in 1980, 10 in 1985 (ToBIAS, 1986: 7) and 6 in 1995 (FERNANDES, 1996: 26). Vilar de Nantes, the second village, near Chaves, at the northern border to Spain, exhibits similar figures: nearly the whole village in the 1950s, 14 in 1978 (FERREIRA, 1983: 20) and 8 in 1995 (FERNANDES, 1996: 17). Furthermore, and in order to respond to this process of decline, both village communities tried to look for new forms of commercialisation, yet finding distinct solutions. Whereas Vilar de Nantes began to sell the earthenware to mobile commerciants who, for their part, sold it for substantially higher prices at fairs in northern Portugal, the potters of Bisalhães tried to benefit from the village's localisation close to a road linking Vila Real and Oporto. Setting up stands and partly even the ovens there, and adapting the design of the pottery to the supposed taste of passing tourists or weekend-trippers, they succeeded in commercialising the majority of their goods in this way. However, the overall tendency of decline could not be stopped thereby, especially since the construction of a motorway between Oporto and Vila Real threatened this possibility of commercialisation.

The training courses carried out by the national employment institute did not also result in a new wave of attraction. Only two young women seem to continue the traditional handicraft, both stemming from pottery families in Vilar de Nantes (FERNANDES, 1996). An attempt to integrate pottery in the primary school lessons failed due to the lack of flexibility of Portuguese bureaucracy: the teaching potter was refused because of his missing academic degree. Likewise, the suggestion to exempt handicraft pottery from industrial taxes could not be put into practice ${ }^{10}$.

There are not only, however, external reasons for the decline of the black pottery. The bad quality of the clay, making the baked pieces rather fragile, as well as the resistance to technical innovations on the part of the potters (in Bisalhães,

10 Personal interview with José Maria Cabral Ferreira in 1997. 
for instance, still today a low wheel is used, which does not allow to model permanently with two hands and requires an extremely uncomfortable working position) have decisively contributed to the continuing process of degradation. As this kind of pottery has been transmitted for generations as a fixed part of the local context, changes were considered a kind of sacrilege. Thus, desistance is easier and even rather accepted than modernisation (FERREIRA, 1983), what obviously might determine the future of black pottery.

2. Promotion of urban culture: bringing the core to the periphery, or the cultural logic of Lisbon'94

The entity European Culture City, established in 1985 by resolution of the European Union Council of Ministers of Culture, presents vague contours as far as goals and working rules are concerned. The document establishing the annual organisation of this event (Resolution 85/C153/2, 13 of July) only mentions the general goal of cultural exchange among the member countries materialised in two immediate or more tangible goals: "...to make easy accessible to the European public certain cultural features of a particular city, region or country" and “... to concentrate in a particular city a certain number of cultural contributions by other member countries to benefit, in the first place, the inhabitants of that particular region". Thus, it is the competence of each member state to appoint the responsible entity for the organisation, management and financing of the events, as well as for the definition of its programme. The aim of this procedure is to guarantee that each chosen city/country may appropriate the project to its specific needs and ambitions.

Lisbon was European Culture Capital in 1994. Thus, attending to the previously exposed flexibility of the European Culture City iniciative, the study of this happening will provide some lessons not only on the logics of urban culture promotion in Portugal but also, in a broader sense, on the logics and problems of cultural policies in peripheral contexts.

Lisbon'94 was promoted in partnership between the central power (State Secretary of Culture) and the local power (Lisbon Municipality), developed by an entity set up on purpose for this - the Sociedade Lisboa'94 - to which several public and private institutions were joined with potential interests or incidence in the area of cultural production (foundations, Lisbon Misericórdia, Institute for External Commerce, etc.). In this sense, Lisbon'94 should also contribute to a structural modernisation of urban (cultural) policy, including entrepreneurial performance, partnership both between national and local and between public and private, and the large use of sponsoring as means to finance interventions (through the establishment of exceptional tax benefits). The latter has been presented as a major success of this initiative - reaching 12\% of Lisbon '94's global budget, or about 960,000 million PTE (SOCIEDADE LISBOA'94, 1995: 87).

According to the promoting authorities, the strategic goals of Lisbon'94 were basically at two inter-related levels, considered extremely valuable for the city, and even for the country. On the one hand, the improvement of competitiveness and 
the consolidation of Lisbon's position in the context of the European urban system, namely with a launching and valorization of the Portuguese capital city as a cultural pole of attraction. On the other hand, the stimulating and dynamising cultural activities, either on the production side (establishment of a favourable environment to cultural innovation, support to producers, etc.) and on the consumption side, creating a new public with new levels of demand. This truly corresponded to the attempt to solve certain well known gaps of Lisbon in this domain whose existence is usually explained by the small size of the internal market.

The projects developed to achieve these goals were visible at several levels, ranging from interventions in the already existing "fixed capital" of Lisbon (cultural heritage, equipments, etc.) to the "import" of cultural services and even to direct intervention in the production market using a "commissioning policy".

Several equipments and infrastructures benefited from Lisbon'94. Besides the works undertaken in Lisbon's Coliseum, that allowed this renovated and enlarged room to hold a capacity of thousands of spectators, the Tivoli cinema was reopened, the National Museum of Ancient Art was improved, Chiado Museum was established using the spolium of the extinct Contemporaneous Art Museum, the Museum of Music was opened and the City Museum was enlarged. These and other interventions to make the museum infrastructure more modern and better equipped (to which several international experts were called) and the initiatives developed in the urban intervention field ${ }^{11}$ did not remain unnoticed to the foreign press $^{12}$ and enhanced Lisbon's tourist potential - a city that makes up for the lack of large pinacothecs with a dense and varied network of small museums and has its main strength in small landscape details and environment.

The development and reinforcement of Lisbon's cultural function in the European context was also achieved through the organisation of events usually limited to international circuits of more qualified cultural shows. This meant an upgrading of Lisbon's performance in this domain. The department responsible for the promotion of Lisbon'94 raised the "placing of Lisbon in the 'map' of cultural capitals (...)" (SOCIEDADE LISBOA'94, 1995: 13). The exhibition The Temptations of Bosch or the Eternal Return, which was presented as one of the big successes of Lisbon'94 (about 50,000 visitors in 3 months, according to the figures of Sociedade Lisboa'94; this is a good result even for international standards), can be quoted as a good evidence of that upgrading. With the exhibition it was possible to bring to Portugal famous world painters (from Goya to Magritte, from Max Ernst to Dali), some of which had never before been shown in Portugal. In what concerns performing arts, Lisbon'94 allowed to present in the Portuguese capital city the last creations of some of the most innovative and famous contemporaneous dancing groups, such as the Wuppertal Dancing Theatre (directed by Pina Bausch)

\footnotetext{
11 One can point out the controversial "Seventh Hill" project, that from the aesthetic and cenographic point of view allowed to improve the romantic route between Cais do Sodré to Largo do Rato.

12 A German newspaper reporting the efforts developed in the enhancement of museums stated that "People will feel better now in Lisbon's museums".
} 
and Fura del Bals (world-wide known after Barcelona Olympic Games). In less than one year 19 orchestras and foreign opera groups (excluding lone soloists) came to Lisbon, as well as several prestigious theatre companies like the National Theatre of London.

Another area in which Lisbon'94 intervened was, as we already mentioned, cultural production. For this purpose, a large contribution was provided by an incentive policy based on the direct commissioning of works, reflecting, however, some strategical contradictions with the above shown "entrepreneurial" principles of government's actions. The orders covered nearly all cultural domains, mostly benefiting Portuguese well-known authors who tried to innovate (including technological innovation, as the first Portuguese High Definition film made by Joaquim Leitão shows). They also tried to privilege "difficult sectors" of cultural industries that are facing market problems (contemporaneous symphonic music being one of the best examples) $)^{13}$.

As can easily be understood from these examples, one can argue that Lisbon'94's programme revealed a clear preference for the promotion of "high culture", including under this designation not only the more conventional arts (opera, ballet, classical music, plastic arts generally) but also certain innovative events, of an almost experimental feature, but still able to be included in that presumed category. It is important to notice that Opera and Classical Music accomplished 149 of the 336 initiatives of the overall programme (44,3\%), summing up a total of 320 performances. To these, more than 50 Dance events must be added, almost totally dedicated to ballet and contemporaneous dance. There were a few exceptions of foreign "ethnic" dance.

This orientation towards the promotion of "high culture", or generally speaking of urban and cosmopolitan culture, was also evident in the exhibitions and reflected in an under-evaluation or even omission of "popular or traditional culture". More than two dozen events were directly sponsored by the Exhibitions sector of Lisbon'94. To this figure one must also add the exhibitions developed by other departments, namely Cinema and Video, Popular Music and Urban Intervention allowing to count more than 30 initiatives of this nature (plastic arts, photography, archaeology, design, architecture, video, etc.). However, in this group only one event was dedicated to Portuguese "traditional culture": the exhibition Fado - Voices and Shadows, shown in the Ethnologic Museum. Not even the ceramic and pottery sector where Portugal has a rich tradition and a well-established imaged abroad was emphasised: the Tile Museum only showed three exhibitions, one being dedicated to the Neapolitan ceramics from the 15th to the 18th century and the other to the Dutch tile! Likewise, the Popular Art Museum, in need of urgent re-animation, was completely left aside in the process of

13 The invitation made to Wim Wenders to shoot in Lisbon, resulting in LisBON STORY, which was presented as world première when closing Lisbon'94, was the main exception. The justification was based on the positive effects on the external visibility of Lisbon since the movie would be launched in the international film circuits and was made by a well-known director. 
modernisation and renovation that Lisbon'94 induced in Lisbon's museums.

It seems that music was the only area in which Lisbon'94 has followed the "valorization of tradition" defending an innovation strategy based on components of traditional culture. Though, it is possible to notice a certain hesitation between choosing "popular culture" and "mass culture": among the events promoted by Lisbon'94 Popular Music department one can distinguish Pink Floyd and Phil Collins' concerts as well as several concerts given by Portuguese rock-pop groups. Anyway, one must not forget two cases which are the best-succeeded examples of implementing that strategy in Lisbon'94. On the one hand, the way fado was dealt with, including a large ethnomusic and document research, ending in the already mentioned exhibition, as well as in a book and two CD editions. We must also add the organisation of several fado shows and two innovative events that tried to reproduce this traditional kind of music using "new languages", namely theatre and modern dance. These two performances were cherished by the critics and surpassed the national frontiers, being presented in several European cities. On the other hand, there was the international relevance achieved by the Madredeus music group after Lisbon Story had been released in the international film circuits. With Wim Wenders, this group, whose musical project well displays the enhancement of local, traditional and popular culture through innovative aesthetic elements, saw its internationalisation process substantially facilitated. Their subsequent world tour ended as a large success both among the public and critics.

\section{III - CULTURE, INNOVATION AND PERIPHERY: DEALING WITH AMBIVALENCES}

In a very broad sense, the relation between periphery and innovation in "classic" theories of regional development or similar fields of investigation has been conceptualised in two opposite ways (see, e.g., FONSECA, GASPAR and VALE, 1996). On the one hand, a "gap" approach seems to force peripheral territories to follow a successful model of economic performance, represented by modernisation or innovation diffusion theories. On the other hand, a "self reliant" approach is rather destined to avoid external influences, fearing their negative impacts on a successful exploitation of endogenous resources such as traditional products or informal structures.

The "valorization of tradition" approach that we have proposed (albeit in a very reduced form) in the course of the present paper provides in itself a distinct, intermediate focus, both in a spatial and temporal dimension ${ }^{14}$. Firstly, as we have tried to emphasise both an internal and an external perspective, specially the interlinkages between these perspectives to the innovation process within the periphery, neither a pure taking up of externally produced success remedies nor a pure endogenous development approach is considered to be the magic path to innovation. Secondly, only the concept of "valorization of tradition" implies that there

14 Although the separation of a temporal and spatial dimension always remains incomplete, therefore merely constituting an analytical tool to facilitate the systematisation. 
is no linear way from tradition to modernity, neither as a force to follow, nor to resist.

The empirical evidence by which we have sought to unravel this complex set of arguments highlights that the "intermediate approach" (that is, the linking of endogenous and catching-up approaches) in reality by no means displays a uniform logic of combination. On the contrary, multiple different combinations of the different logics can be found, chiefly constituting different attempts to deal with the ambivalences that the proposed intermediate way of innovation implies. In this final section we will show three in our view fundamental dimensions of these ambivalences, simultaneously trying to point out some of their policy implications.

The first ambivalence can be considered as one of the dominant features of government's action in a (semi-)peripheral context. In the case of Portuguese state it seems worthwhile to use Boaventura de Sousa Santos' theses on the political conditions within Portuguese society in order to recognise the structural paradox its historical evolution has been based upon, namely the fact that Portugal "... has been for many centuries simultaneously the centre of a huge colonial emporium and the periphery of Europe ..." or, in other words, "... the only colonising country to be considered by other colonising countries as a native or wild country” (SANTOS, 1995: 59).

This contradiction became evident as a problem to be lived and to deal with when Portugal lost its African colonies in the 70s. It was necessary to "re-negotiate" the country's position in the world-system being able to maintain the image of centrality that colonies had provided before. European integration filled the empty space left by the loss of the metropolitan function, at the same time reproducing the peripherality in the continental context. The state performance that resulted from this somehow curious situation is conceptualised by Boaventura de Sousa Santos using the term "state-as-imagination-of-centre" (SANTOS, 1993: 51), thereby describing the way Portuguese national policy tries to symbolically "regulate" the "dialectics of difference and identity between Portugal and Europe": "The regulation consists in the creation of an imaginary universe where Portugal is transformed in a European country equal to the others, the minor degree of development being considered a transitory characteristic which has to be dealt with and gradually and irreversibly attenuated by the state in the capacity of the guardian of national interest". The political discourse should make believe that "... to be with Europe is to be Europe" (SANTOS, 1995: 58).

Lisbon'94 nearly completely mirrors this logic, transmitting the idea of the Portuguese capital ranking among the "front platoon" 15 of European culture, without providing an important own cultural contribution, except in the case of traditional popular music. Furthermore, the stimulation of an enhanced cultural live which could strengthen an endogenous identity and maybe have economic spin-off effects did not occur. The cultural identity was purely "pulled" to Lisbon following the above shown logic.

15 "O pelotão da frente" is an expression used by Cavaco Silva as prime-minister to name the more developed countries, in which group he victoriously included Portugal. This expression well displays the mentioned idea of "state-as-imagination-of-centre". 
This logic of state performance, however, is not only evident in the case of the management of Lisbon'94. The missing academic degree of the potter who was supposed to teach his handicraft to primary school pupils in order to revive it in the local context displays an exaggerated idea of what it means not to be peripheral, the appropriate diploma being considered a precondition to attenuate the backwardness to Europe.

The second ambivalence is based upon the fact that the valorization of tradition does never function purely, being always accompanied by a certain degree of modernisation (of a product, of a process, of agents' performance, etc.). In this sense, it consists of the outcome of this modernisation process. On the one hand, the process is necessary so as to make valorization possible at all. On the other hand, it necessarily implies a process of adulteration, respectively a loss of authenticity of the tradition, so to speak a certain separation of its origin. All involved agents will have to assume this ambivalence, and our cases display again different ways regarding this assumption. The cock of Barcelos may be the most extreme case of a total break away from its traditional context (in a historically wrong way) used to label the puppet for its tourist use.

The other extreme is constituted by Rosa Ramalha, whose puppets caused a dialogue between different worlds just because of their originality and authenticity. There was, for a short period and certainly as an exceptional case, an appreciation of pure tradition on the part of a more modernised society, supported by modern media and by more modern forms of commercialisation. But Rosa was able to maintain the quality that had been appreciated in her work. And this quality could be the point of departure for the political dealing with this ambivalence. Besides assuming it, policy will have to intervene in a creative, quality-oriented way in order to guarantee the generation of "new authenticities".

The third ambivalence is closely connected with the second one, even based upon the same fact, namely that valorization of tradition entails its integration into a wider context, that is, the capture of new or wider markets. The ambivalence in itself consists in the missing capacity of the traditional system to manage this step, or, more abstractly, that the tradition which fostered the creation of nowadays valorized products, at the same time hinders successful economic performance. A very clear example in this sense can be taken from agriculture: the egocentrism of minifundian households has caused a high degree of biodiversity within the local ecological system, thereby resulting in the production of food with a high biological value. The same egocentrism, however, hinders a successful commercialisation of these products, by blocking the association of farmers, the joint creation of a uniform product label etc.. Handicraft producers, stemming from a similar cultural context, follow the same logic, being unable to leave their traditional context without an external input, as well as adapting their products to a wider market. In the same sense as black pottered miniatures of vases may be sold to passing tourists but will never succeed in capturing wider markets, pure traditional popular music would have to display an extraordinary quality or rarity to successfully perform. 
The blue tableware, made from a Provençal design but involved in the traditional local context of Portuguese pottery, as well as the modern "upgrading" of Portuguese traditional music à la Madredeus show that it is possible to combine modern and traditional, as well as endogenous and externally produced elements to an authentic product, to deal successfully with the ambivalences of an innovation process within the periphery.

This paper has surely been a mere sketch, a first approach with only little representative case studies which, firstly, have shown a tremendous diversity and, secondly, took different perspectives to the phenomenons. However, to understand the "dealing with ambivalences" as a key factor for the culture-innovation nexus in the periphery seems a valuable concept at least to start with. To deal successfully with these ambivalences of peripheral or semi-peripheral modernisation processes may be a necessary precondition for a "culturally coloured" innovation policy as well. Otherwise, it runs the risk to merely produce ephemeral events with some repercussions within the international press such as Lisbon'94. Next year, Lisbon will repeat this story, in an even larger dimension. We will see if the Expo 98 can be a real attempt to successfully link tradition and modernisation in a peripheral capital of Europe.

\section{ACKNOWLEDGEMENTS}

The authors would like to thank above all the interviewed persons, especially Eugénio Lapa Carneiro for three and a half inspiring hours spent in the Portuguese National Library. Furthermore, this reviewed version relies heavily on comments from the EUNIT International Conference, especially from Maria Lucinda Fonseca and Richard Kötter. 


\section{REFERENCES}

ADORNO, Th. (1991) - The Culture Industry. Selected essays on mass culture. Routledge, London.

AG KULTURWIRTSCHAFT (1995) - Culture and media-industries in the regions of North-Rhine-Westphalia. $2^{\text {nd }}$ Culture Industries Report. Summary. Ministerium für Wirtschaft, Mittelstand, Technologie und Verkehr des Landes Nordrhein-Westfalen, Düsseldorf.

ALMEIDA, C. A. FerREIRA DE (1990) - Barcelos. Editorial Presença, Lisbon.

AMIN, A.; N. THRIFT (1992) - Neo-Marshallian nodes in global networks. International Journal of Urban and Regional Research, 16: 571-587.

AmIN, A.; N. Thrift (1994) - Living in the global. in A. Amin and N. Thrift (eds.). Globalisation, institutions and regional development in Europe, Oxford University Press, Oxford: 1-22.

BRAUDEL, F. (1985) - La dynamique du Capitalisme. Les Éditions Arthaud, Paris.

CAVACO, C.; A. SAMPAIO RAMOS (1994) - Do despovoamento rural ao desenvolvimento local. Programa das Artes e Oficios Tradicionais, Lisbon.

FERNANDES, I. M. (1996) - Centros produtores da louça preta da região Norte. Revista Olaria, 1:11-36.

FERNANDES, I. M. (without year) - Lista dos centros produtores da louça preta, unpublished list.

FERREIRA, J. M. CABRAL (1983) - Artesanato, cultura e desenvolvimento regional. Um estudo de campo e três ensaios breves. Imprensa Nacional - Casa da moeda, Lisbon.

Flowers, N. (1967) - La vieille dame digne de Barcelos. Sciences et Voyages. La Vie des Hommes, 29 (Sept.): 26-32.

FonSECA, M. L.; J. GASPAR; M. VALE (1996) - Innovation, territory and industrial development in Portugal. Finisterra - Revista Portuguesa de Geografia, XXXI (62): 29-44.

GrABHER, G. (1993) (ed.). - The Embedded Firm: On the Socioeconomics of Industrial Networks. Routledge, London/New York.

HARVEY, D. (1989) - The condition of postmodernity. An enquiry into the origins of cultural change. Basil Blackwell, Oxford/Cambridge.

HENRIQUES, E. BRITO (1996) - A Lisboa turística, entre o imaginário e a cidade. A construção de um lugar turístico urbano. Edições Colibri, Lisbon.

HUDSON, R. (1995) - Making music work? Alternative regeneration strategies in a deindustrialised locality: the case of Derwentside. Transactions, Institute of British Geographers, 20: 460-473.

IPSEN, D. (1986) - Neue urbane Zonen - Raumentwicklung und Raumbilder. in J. FRIEDRICHS, H. HÄUßERMANN and W. SIEBEL (eds.). Süd-Nord-Gefälle in der Bundesrepublik?, Westdeutscher Verlag, Opladen: 142-152.

IPSEN, D. (1988) - Vom allgemeinen zum besonderen Ort. Zur Soziologie räumlicher Ästhetik. in H. SPITZER et al. (eds.). Raumästhetik, eine regionale Lebensbedingung, Forschungsgesellschaft für Agrarpolitik und Agrarsoziologie, Bonn: 13-33.

IPSEN, D. (1990) - Nach-moderne Perspektiven der Tradition. Eine Untersuchung bäuerlicher, handwerklicher und industrieller Handlungsmuster im Vogelsberg. in H. SPITZER et al. (eds.). Lebensbedingungen im Vogelsberg, Forschungsgesellschaft für Agrarpolitik und Agrarsoziologie, Bonn: 70-87.

IPSEN, D. (1993) - Regionale Identität. Überlegungen zum politischen Charakter einer psychosozialen Raumkategorie. Raumforschung und Raumordnung, 93 (1): 9-18.

JACKSON, P.; J. TAYLOR (1996) - Geography and the cultural politics of advertising. Progress in Human Geography, 20 (3): 356-371. 
JAMESON, F. (1984) - Postmodernism or the cultural logic of late capitalism. New Left Review, 146: 52-92.

KNOX, P.; J. AGNEW (1989) - The geography of the world-economy. An introduction to economic geography. Edward Arnold, London/New York (2nd ed., 1994).

KUNZMANN, K. R. (1995) - Strategien zur Förderung regionaler Kulturwirtschaft. in T. HEINZE (ed.). Kultur und Wirtschaft. Perspektiven gemeinsamer Innovationen, Westdeutscher Verlag, Opladen: 324-342.

LAGE, F. et al. (1940) - Vida e arte do povo português. Secretaria de Propaganda Nacional, Lisbon.

LÄPPLE, D. (1991) - Essay über den Raum. Für ein gesellschaftswissenschaftliches Raumkonzept. in H. HÄUßERMANN and D. LÄPPLE (eds). Stadt und Raum. Soziologische Analysen, Centaurus-Verlag, Pfaffenweiler: 157-207.

LÄPPLE, D. (1994) - Zwischen gestern und übermorgen. Das Ruhrgebiet - eine Industrieregion im Umbruch. in R. KREIBICH et al (eds.). Bauplatz Zukunft. Dispute über die Entwicklung von Industrieregionen, Klartextverlag, Essen: 37-51.

LINDNER, R. (1994) (ed.) - Die Wiederkehr des Regionalen. Über neue Formen kultureller Identität. Campus-Verlag, Frankfurt/New York.

MARQues, C. P.; J. F. G. PorTEla (1994) - Actividades tradicionais e emprego feminino no Montemuro: Notas de reflexão sobre o desenvolvimento local. Gestão e Desenvolvimento, 3: 175-185.

MOREIRA, J. (1994) - Os artesãos e as artes e oficios tradicionais. Esboço de um retrato. Programa das Artes e Oficios Tradicionais, Lisbon.

NORTH, D. C. (1991) - Institutions. Journal of Economic Perspectives, 5 (1): 97-112.

Peixoto, A. A. Rocha (1899) - As olarias de Prado. Museu Regional de Cerâmica, Barcelos (2nd ed., 1966).

SABEL, C. F. (1989) - The reemergence of regional economies. WZB discussion paper, Forschungsschwerpunkt Arbeitsmarkt und Beschäftigung (IIMV), Berlin.

SANTOS, B. de Sousa (1993) - O estado, as relações salariais e o bem-estar social na semiperiferia: o caso português. in B. de Sousa Santos (ed.). Portugal: um retrato singular, Edições Afrontamento, Oporto: 17-56.

SANTOS, B. de Sousa (1995) - Pela mão de Alice. O social e o político na pós-modernidade. Edições Afrontamento, Oporto.

SAYER, A. (1994) - Cultural studies and "the economy, stupid". Environment and Planning D: Society and Space, 12: 635-637.

ScOTT, A. J. (1996) - The craft, fashion, and cultural-products industries of Los Angeles: Competitive dynamics and policy dilemmas in a multi-sectoral image-producing complex. Annals of the Association of American Geographers, 86 (2): 306-323.

SOCIEDADE LiSBOA'94 (1995) - Lisboa'94, Capital Europeia da cultura - Memória fotográfica. Lisboa'94, Lisbon.

STORPER, M. (1995) - The resurgence of regional economies, ten years later: The region as a nexus of untraded interdependencies. European Urban and Regional studies, 2 (3): 191-221.

THIEL, J. (1995) - Trás-os-Montes/Portugal. Die europäische Peripherie und die Ambivalenz von Rückständigkeit und Modernisierung. MA Dissertation in spatial planning, Universität Dortmund, Dortmund.

TOBIAS, W. (1986) - Schwarze Keramik aus Nordportugal. Ein Bericht über die Arbeit der Töpfer in Bisalhães - Vila Real, Rasch Verlag, Bramsche.

WALLERSTEIN, I. (1974) - The modern world-system I. Capitalist agriculture and the origins of the European world-economy in the sixteenth century. Academic Press, San Diego 